\title{
SISTEM INFORMASI KENAIKAN GAJI BERKALA PNS PEMERINTAH PROVINSI KEPULAUAN RIAU
}

\author{
Hendranita Sitorus ${ }^{1}$, Mochammad Rizki Romdoni ${ }^{2}$ \\ 1,2 Jurusan Teknik Informatika STT Indonesia Tanjungpinang \\ ${ }^{1,2}$ Jln. Pompa Air No. 28 Tanjungpinang Kepulauan Riau Indonesia \\ 1shendranita@gmail.com \\ ${ }^{2}$ rizki@sttindonesia.ac.id
}

\begin{abstract}
Intisari - Kenaikan gaji berkala (KGB) merupakan suatu jenis kenaikan gaji yang diberikan kepada pegawai negeri sipil (PNS) yang telah mencapai masa kerja golongan yang ditentukan untuk kenaikan gaji berkala yaitu setiap dua tahun sekali dan apabila telah memenuhi persyaratan berdasarkan peraturan perundang - undangan yang berlaku. Proses pembuatan surat kenaikan gaji berkala (KGB) Pemerintah Provinsi Kepulauan Riau masih dilakukan secara manual yaitu dengan diketik satu per satu dan disimpan di komputer admin kepegawaian, sehingga memungkinkan terjadinya kesalahan SK KGB yang dibuat dan memungkinkan adanya file yang hilang. Berdasarkan permasalahan di atas, dibutuhkan sebuah Sistem Informasi Kenaikan Gaji Berkala berbasis website yang memudahkan kepegawaian dalam membuat SK Kenaikan Gaji Berkala.

Metodologi pengumpulan data yang digunakan penulis meliputi wawancara dan penelitian kepustakaan untuk memperoleh datadata. Penulis merancang sistem dengan penggambaran pemodelan system yaitu menggunakan metode terstruktur yang dimulai dari diagram konteks (Context Diagram), DFD (Data Flow Diagram), ERD (Entity Relationship Diagram).

Hasil yang diperoleh pada penelitian ini adalah Sistem Informasi Kenaikan Gaji Berkala yang dapat mengelola proses pembuatan SK Kenaikan Gaji Berkala, mengelola persyaratan KGB, dan mengelola SK KGB hingga diterima oleh Badan Pengelola Kekayaan dan Aset Daerah Provinsi Kepulauan Riau.
\end{abstract}

Kata kunci-Sistem Informasi, Kenaikan Gaji Berkala, Kepegawaian

Abstract - Periodic Salary Increases is a kind of salary increases given to civil servants once in two years who is qualified according to the law. Making a Periodic Salary Increases Letter in Provincial Government of Riau Island. is still in manual process by typing the letter one by one and saved in Staffing Administrator's computer. This might cause an incorrect in Periodic Salary Increases Decree. Moreover, any trouble in the administrator's computer could also cause files lost and make Periodic Salary Increases Decree arrived late at BPKAD of Province of Riau Island.. From cases above, we need a Periodic Salary Increases Information System based on website to support Staffing create Periodic Salary Increases Decree.

Author design a modeling system using structured method: Context Diagram, DFD, and ERD (Entity Relationship Diagram). This research produce Periodic Salary Increases Information System to process Periodic Salary Increases Decree, requirements, and to produce Periodic Salary Increases Decree until it suitable to send to BPKAD of Province of Riau Island.

Keywords - Information System, Periodic Salary Increases Decree, Staffing.

\section{Pendahuluan}

Perkembangan teknologi informasi saat ini mengalami peningkatan yang sangat pesat. Hal ini ditandai dengan sejumlah instansi pemerintahan, dalam memberikan pelayanan dengan penerapan sistem yang terkomputerisasi. Berhubungan dengan perkembangan teknologi dan informasi tersebut, kenaikan gaji berkala merupakan hak bagi setiap PNS yang diberikan saat pegawai tersebut telah mencapai masa kerja golongan yang ditentukan untuk kenaikan gaji berkala yakni setiap 2 tahun sekali dan apabila telah memenuhi persyaratan berdasarkan Peraturan Pemerintah nomor 7 tahun 1977 tentang gaji PNS, banyak instansi pemerintah berusaha untuk melakukan pengembanganpengembangan sistem yang serba terkomputerisasi sesuai dengan kebutuhannya.

Masalah pengajuan kenaikan gaji berkala merupakan tugas pokok Subbag Umum dan Kepegawaian masing-masing
SKPD. Saat ini pengelolaan laporan kenaikan gaji berkala masih secara manual, yaitu dengan melihat data PNS di buku dan disimpan kedalam Microsoft Excel dan data SPTKG (Surat Putusan Kenaikan Gaji Berkala) serta melihat data Peraturan Pemerintah tentang gaji berkala, Dalam melakukan penghitungan kenaikan gaji berkala sesuai pangkat atau golongan masih sepenuhnya dilakukan secara manual yang dilihat dari SK terakhir yang diarsipakan dan disesuaikan dengan Peraturan Pemerintah tentang gaji berkala.

Subbag Umum dan Kepegawaian yang bergerak dibidang penyimpanan dan perekapan dokumen arsip KGB ini terbatas untuk melakukan proses pengolahan data, dimana proses pengolahan data masih menggunakan komputer yaitu dengan menggunakan Ms. Office Excel dan Ms.Word. Namun penggunaan Ms. Office Excel dan Ms. Word belum optimal, dikarenakan tidak jarang terjadi human eror dan petugas juga mengalami kesulitan pada saat pengimputan data baru dan mencetak laporan, dimana sistem pencatatan dan perekapan 
data saat ini masih memiliki kekurangan dalam hal pengiriman data KGB masing-masing OPD dan pembuatan laporan. Saat ini untuk berkas data KGB akan dikirim dan ditujukan ke BPKAD untuk dilakukan verifikasi dan jika sudah sesuai maka dapat dilanjutkan untuk proses kenaikan gaji berkala.

Laporan-laporan yang dibutuhkan masih terbatas, oleh sebab itu diperlukan adanya pengembangkan sistem pendataan secara terkomputerisasi yang lebih baik, berdasarkan latar belakang yang telah diuraikan diatas maka peneliti tertarik untuk melakukan penelitian yang akan dijadikan sebagai skripsi yang mengkhususkan pada pengelolaan data kenaikan gaji pegawai secara bekala dengan judul "SISTEM INFORMASI KENAIKAN GAJI BERKALA PNS PEMERINTAH PROVINSI KEPULAUAN RIAU".

\section{Metodologi Penelitian}

\section{a. Metode Pengumpulan Data}

\section{Interview}

Peneliti melakukan wawancara langsung pada Subbag Umum dan Kepegawaian pada Dinas Perpustakaan dan Kearsipan Provinsi Kepulauan Riau dan bagian Perbendaharaan pada Badan Pengelolaan Kekayaan dan Aset Daerah Provinsi Kepulauan Riau sebagai bahan dalam penelitian skripsi.

\section{Studi Pustaka}

Peneliti mencari bahan-bahan atau materi sumber yang dapat di gunakan sebagai referensi atau mencari hal-hal yang dapat digunakan dalam membuat sistem informasi kenaikan gaji berkala Pegawai.

\section{b. Metode Pengembangan Perangkat Lunak}

Metode pengembangan perangkat lunak pada pembuatan sistem informasi ini adalah menggunakan model Waterfall. Metode Waterfall ini memudahkan dalam melakukan penelitian karena lebih terstruktur, dinamis dan sekuensial. Metode pengerjaan dari suatu sistem dilakukan secara berurutan atau secara linear.

\section{HASIL DAN PEMBAHASAN}

\section{a. Flowmap Prosedur Permohonan Pembuatan SK \\ KGB PNS}

Adapun Proses atau langkah-langkah dari permohonan pembuatan SK KGB PNS yang diusulkan dalam sistem informasi kenaikan gaji berkala ini adalah sebagai berikut :

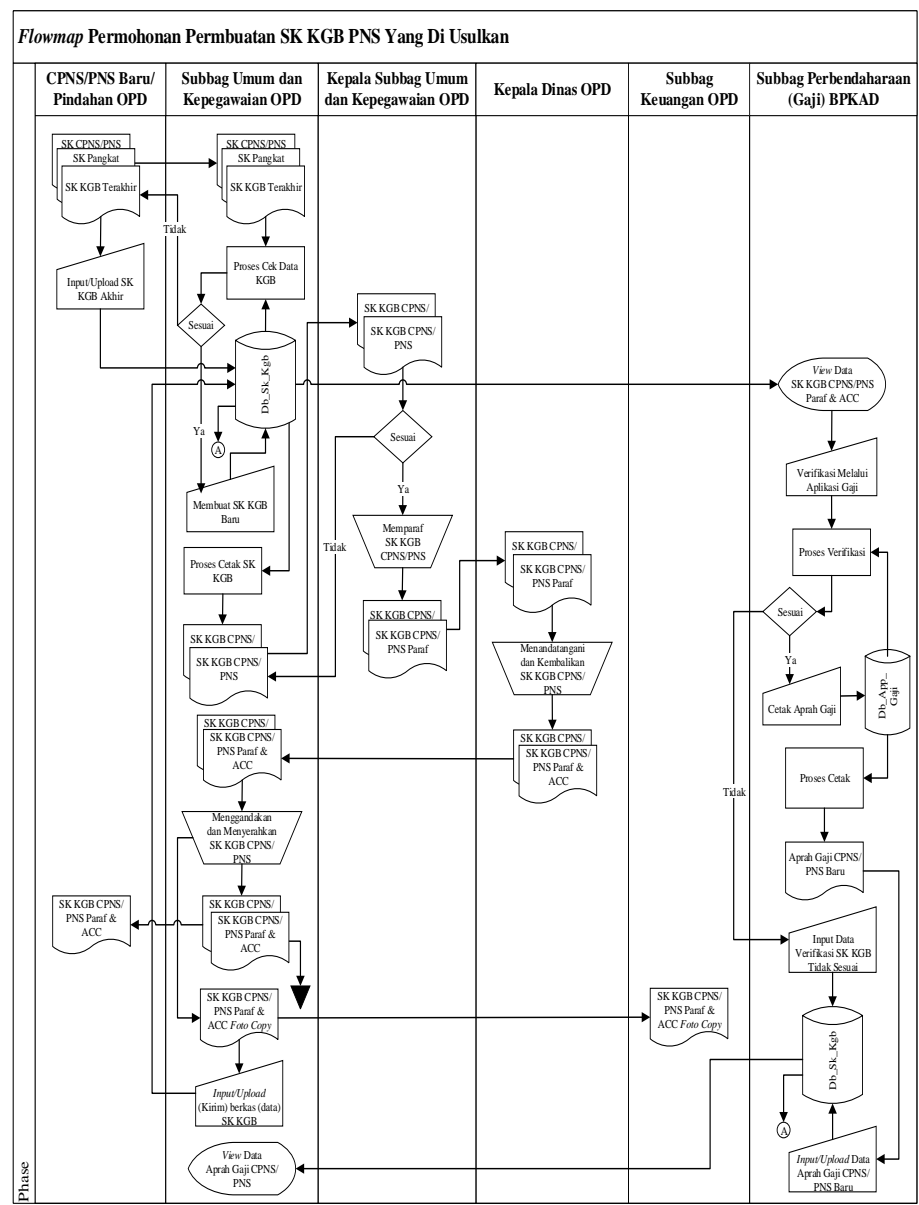

Gambar 4.1 Flowmap Permohonan Pembuatan SK KGB PNS

b. Context Diagram (Diagram Konteks)

Diagram konteks dari system (aplikasi) usulan yang telah dirancang adalah sebagai berikut :

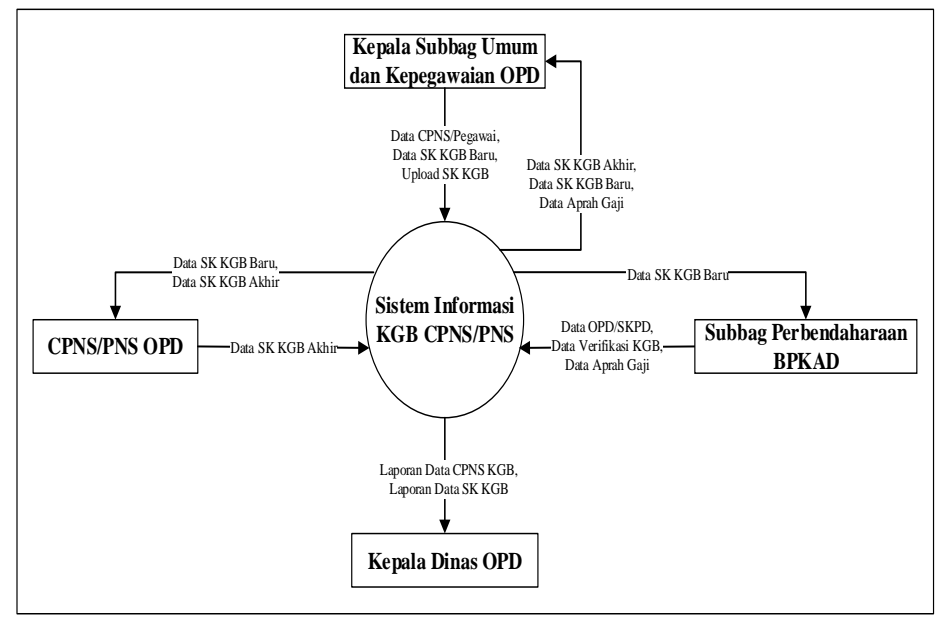

Gambar 4.2 Diagram Konteks

Gambar 4.2 merupakan diagram sederhana yang menggambarkan hubungan antara entity luar yaitu CPNS/PNS, Subbag Umum dan Kepegawaian dan perbendaharaan BPKAD, hubungan yang dimaksud berupa masukan dan keluaran dari sistem informasi kenaikan gaji berkala. 


\section{c. Data Flow Diagram (diagram arus data)}

Data Flow Diagram (diagram arus data) dari system yang telah dirancang adalah sebagai berikut :

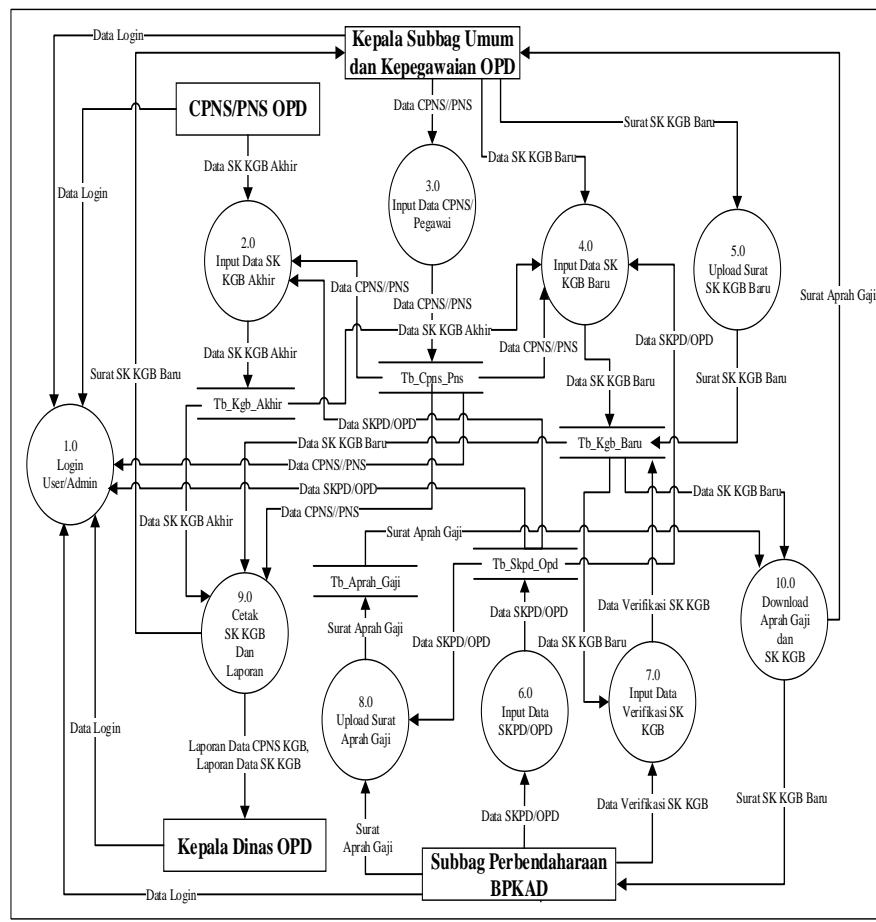

Gambar 4.3 Data flow diagram (Dfd) level 0

Gambar 4.3 menggambarkan arus data dalam sistem informasi kenaikan gaji berkala dari mulai login, upload file kgb sampai dengan keluarnya data berupa output yaitu file amprah gaji yang diupload kembali oleh BPKAD di sistem.

\section{d. Entity Relation Diagram (ERD)}

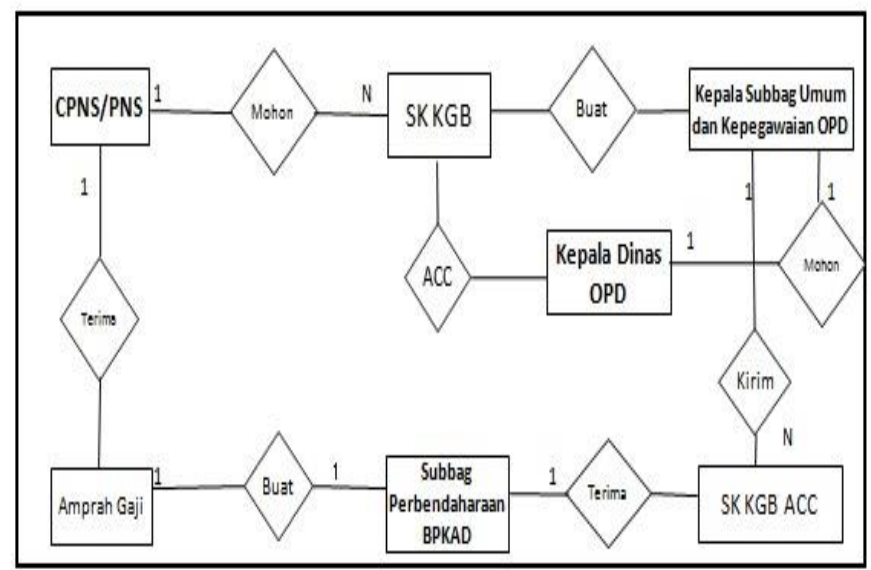

Gambar 4.5 Entity Relationship Diagram

Gambar 4.5 menggambarkan hubungan antar entitas dalam sistem. Semua data store di DFD dijadikan entitas di ERD, yaitu CPNS/PNS, SK KGB, Kasubbag Umum Kepegawaian dan amprah gaji.

\section{e. Implementasi Sistem}

1. Tampilan Halaman Utama (Login)

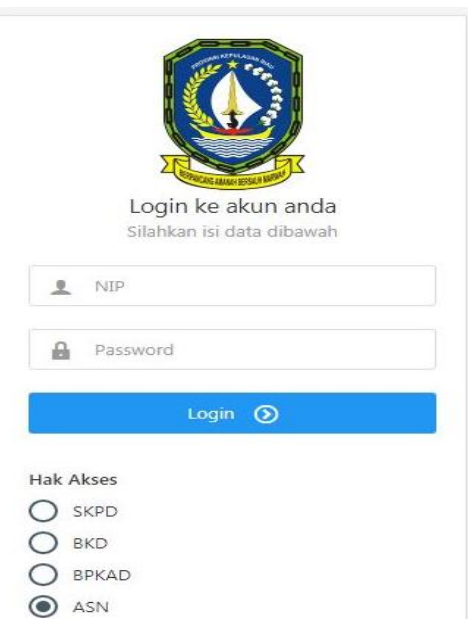

Gambar 4.6 Tampilan Halaman Utama

2. Tampilan Halaman Utama PNS

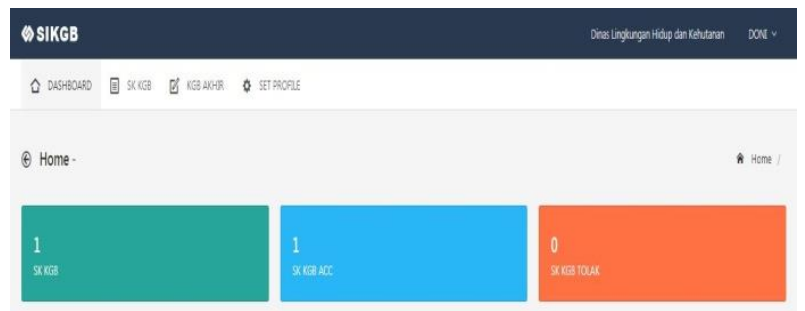

Gambar 4.7 Tampilan Halaman Utama PNS

3. Tampilan Tambah Data KGB Akhir

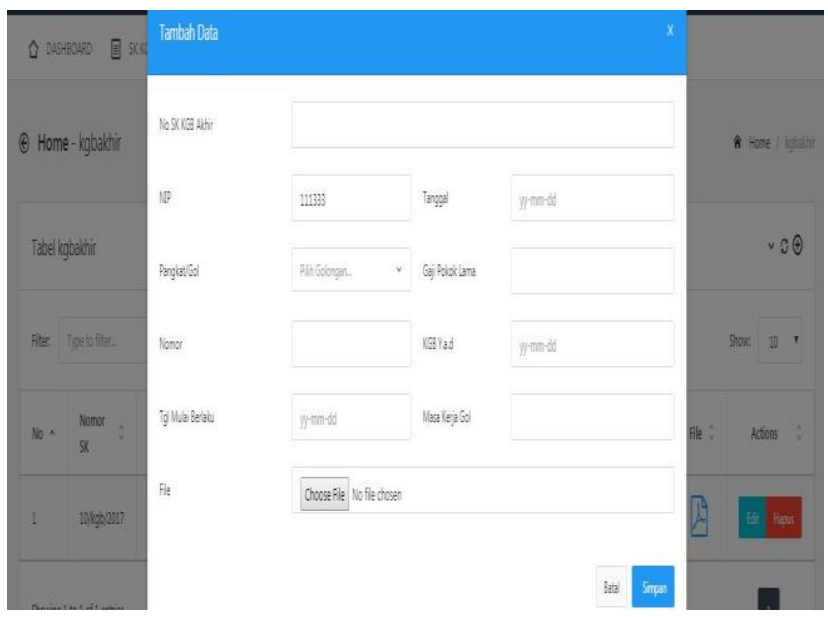

Gambar 4.8 Tampilan Tambah Data KGB Akhir 
4. Tampilan Edit Data KGB Akhir

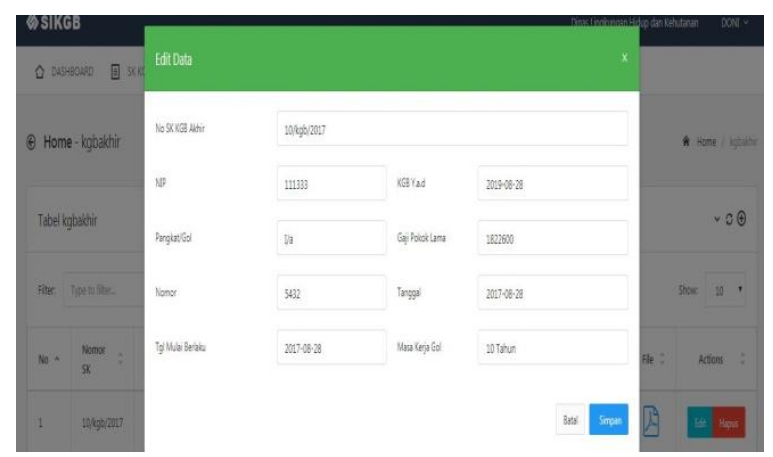

Gambar 4.9 Tampilan Edit Data KGB Akhir

5. Tampilan KGB Akhir

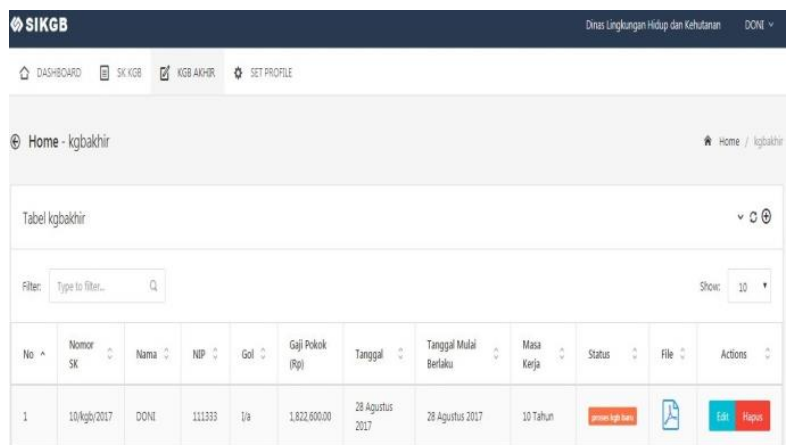

Gambar 4.10 Tampilan KGB Akhir

6. Tampilan Halaman Utama SKPD

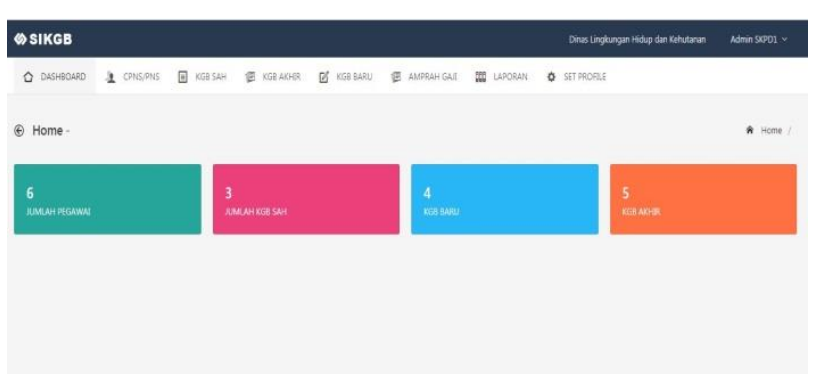

Gambar 4.11 Halaman Utama SKPD

\section{Tampilan Data PNS}

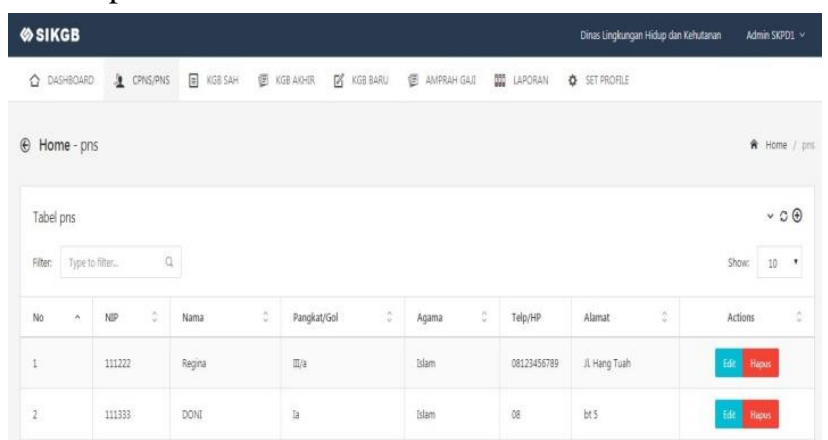

Gambar 4.12 Tampilan Data PNS
8. Tampilan Input Data PNS

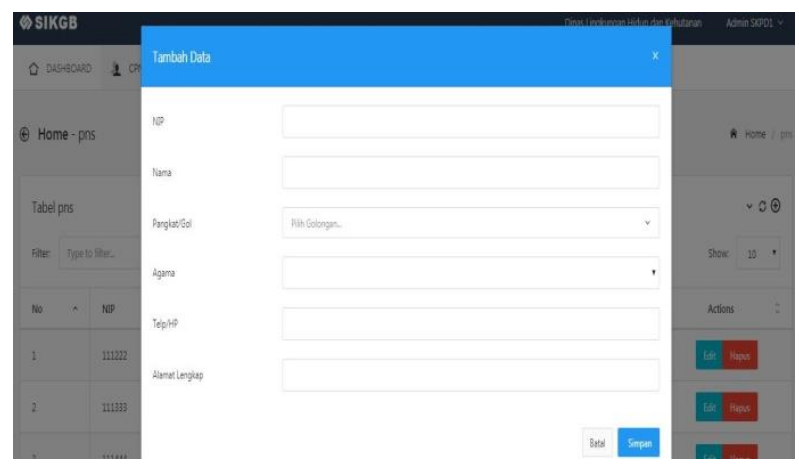

Gambar 4.13 Tampilan Input Data PNS

9. Tampilan Input Data KGB Baru

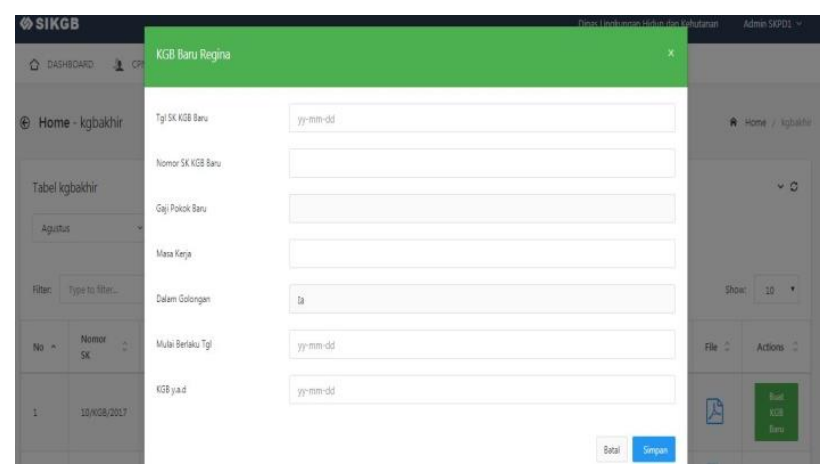

Gambar 4.14 Tampilan Input Data KGB Baru

10. Tampilan Data KGB Baru

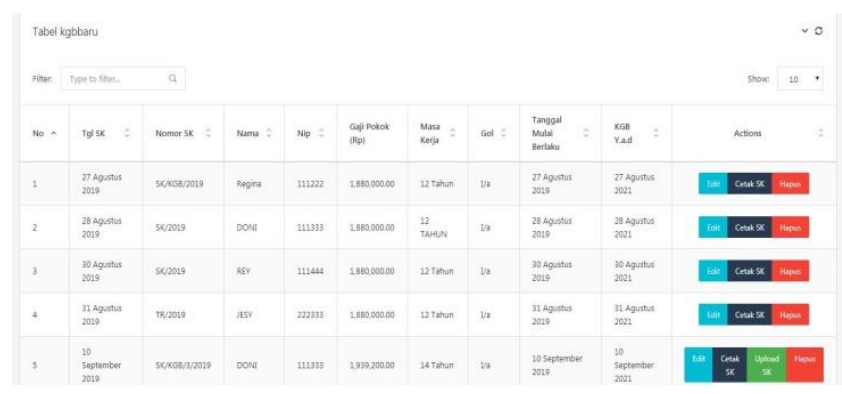

Gambar 4.15 Tampilan Data KGB Baru

11. Tampilan Edit Data KGB Baru

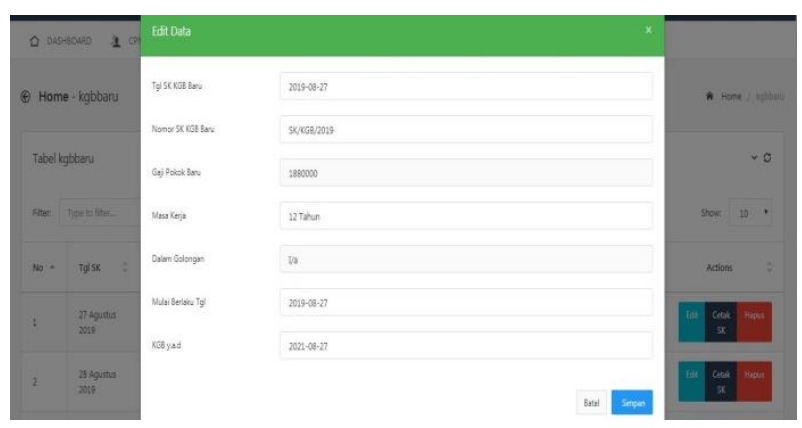

Gambar 4.16 Tampilan Edit Data KGB 
12. Laporan Data KGB

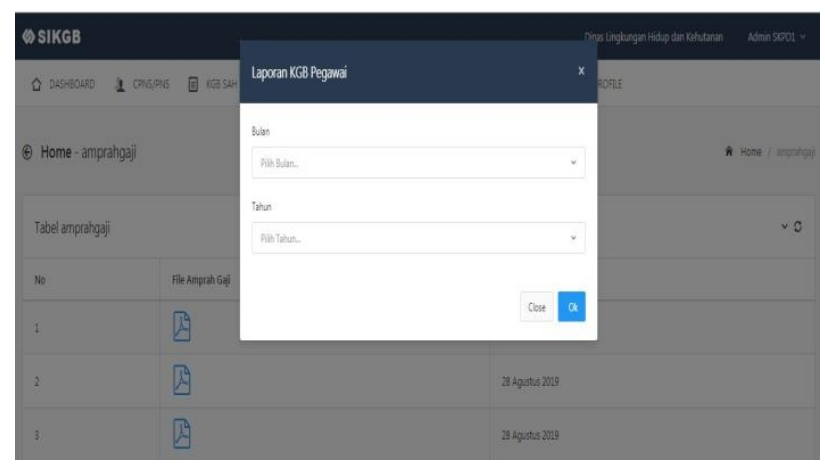

Gambar 4.17 Tampilan Laporan Data KGB

13. Tampilan Halaman Utama BPKAD

\section{GSIKEB}

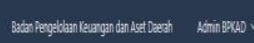

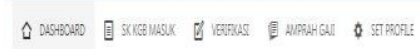

$\theta$ Home-wecome
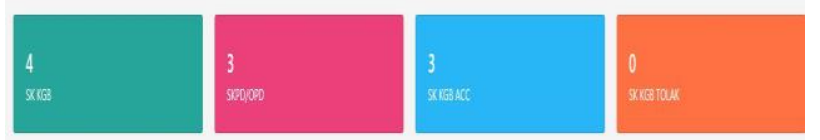

Gambar 4.18 Tampilan Halaman Utama BPKAD

\section{Tampilan KGB Baru Masuk}

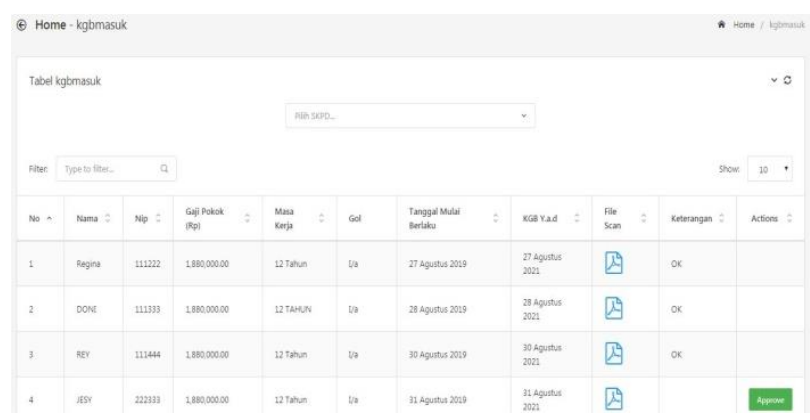

Gambar 4.19 Tampilan KGB Baru Masuk

\section{Tampilan Verifikasi KGB Baru}

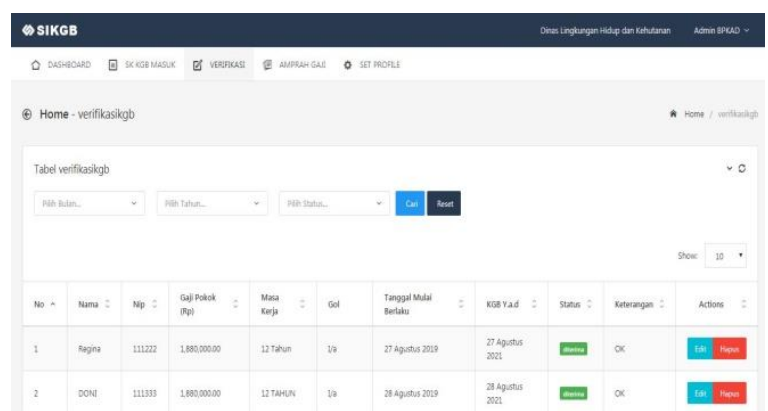

Gambar 4.20 Tampilan Verifikasi KGB Baru

\section{Tampilan Upload Amprah Gaji}

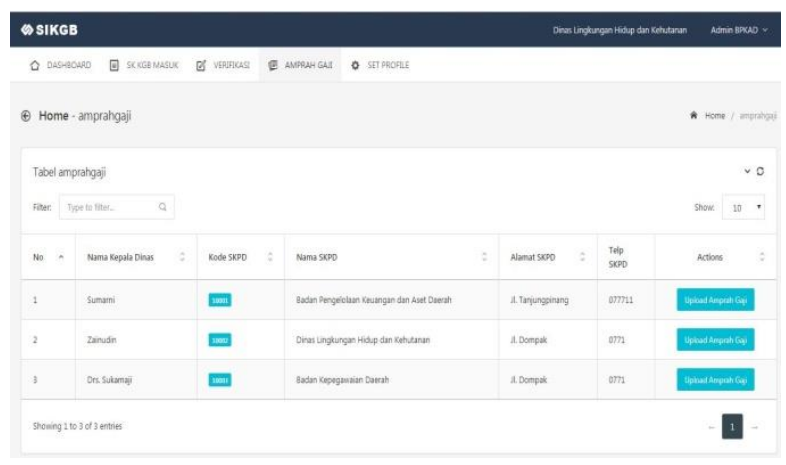

Gambar 4.21 Tampilan Upload Amprah Gaji

\section{KESIMPULAN}

Setelah dilakukan analisis, perancangan, implementasi dan pengujian pada Sistem Informasi Kenaikan Gaji Berkala (KGB) PNS Pemerintah Provinsi Kepulauan Riau, maka kesimpulan yang didapat adalah:

a. Telah dibuatnya Sistem informasi berbasis website yang dapat memproses penginputan dan pengarsipan data kenaikan gaji berkala pegawai dengan mudah dan efisien

b. Telah dibuatnya Sistem informasi berbasis website yang dapat melakukan pengimputan data kenaikan gaji berkala pegawai yang disesuaikan dengan pangkat/golongan dengan mudah dan akurat

c. Telah dibuatnya Sistem informasi berbasis website yang mampu melakukan proses pencarian data kenaikan gaji berkala pegawai dengan cepat

Adapun saran yang dapat diberikan untuk penyempurnaan dari sistem ini adalah:

a. Mengembangkan desain dan menu sistem informasi misalnya dengan menambahkan menu online chatting.

b. Perlu dilakukan penelitian lebih lanjut agar sistem informasi Kenaikan Gaji Berkala ini dapat diterapkan pada perangkat mobile smartphone sehingga kelak sistem informasi ini lebih mudah diakses darimana saja dan kapan saja.

\section{REFERENSI}

[1] Kristanto, Andri, Perancangan Sistem Informasi dan Aplikasinya (Edisi Revisi), Gava Media, 2018, Yogyakarta

[2] MF, Mundzir, Buku Sakti Pemrograman Web Seri PHP, Start Up, 2018, Yogyakarta

[3] Raharjo, Budi, Belajar Otodidak Membuat Database Menggunakan MySQL[Bandung - Informatika, 2013

[4] Rosa A. S. dan M. Shalahuddin, Rekayasa Perangkat Lunak Terstruktur dan Berorientasi Objek, Informatika, April 2018, Bandung

[5] Salinan Peraturan Pemerintah Nomor 7 Tahun 1977 tentang Peraturan Gaji Pegawai Negeri Sipil sebagaimana telah diubah dengan Peraturan Pemerintah Nomor 66 Tahun 2005

[6] Salinan UU Nomor 8 Tahun 1974 Tentang Pokok-Pokok Kepegawaian

[7] Tim Penyusun, Buku Panduan Penulisan Laporan Kerja Praktek (KP) dan Skripsi, Tanjungpinang, Sekolah Tinggi Teknologi Indonesia, 2014

[8] [8] Hutahaean Jeperson , Konsep Sistem Informasi [Yogyakarta - Deepublish, 2014, [Online] Available : https://books.google.co.id/books?isbn=6022806720, [2019, Maret 04/12:16], Hal. 3-5 
[9] [9] Lisabet Yunaeti Anggraeni dan Rita Irviani, Pengantar Sistem Informasi [Yogyakarta - CV. Andi, 2017, [Online] Available : https://books.google.co.id/books?isbn=9792962778 [2019, Maret 04/10:16], Hal. 12

[10] Mudradad Kuncoro, Metode Riset untuk Bisnis \& Ekonomi:Bagaimana Meneliti dan Menulis Tesis? [Jakarta - Erlangga, 2013], hal.124

[11] Mustaqbal, M. Sidi, Roero Fajri Firdus, Hendra Rahmadi, Pengujian Aplikasi Menggunakan Black Box Testing Boundary Value Analysis. Jurnal Ilmiah Teknologi Informasi Terapan, 2015 [Online] Tersedia di: jitter.widyatama.ac.id/index.php/jitter/article/view/70/50.pdf [diunduh: 09 Maret 2019], hal. 34

[12] Suprayitno dan Uli Indah Wardati,"Pembangunan Sistem Stok Barang Dan Penjualan Pada Toko Sero Elektronik", IJCSS-Indonesian Jurnal on Computer Science Speed. Vol.9, 2012 [Online] Tersedia di:http://mahasiswa.dinus.ac.id/docs/skripsi/jurnal/12033.pdf [diunduh: 19 April 2019] hal. 96).
[13] Syukron, Akhmad dan Noor Hasan, Perancangan Sistem Informasi Rawat Jalan Berbasis Web pada Puskesmas Winong, Jurnal Bianglala Informatika, Vol.3, No.1, 2015 [Online] Tersedia di: https://www.academia.edu/19567789/Perancangan_Sistem_Informasi Rawat_Jalan_Berbasis_Web_Pada_Puskesmas_Winong [diunduh: 19 April 2018], hal. 29

[14] Tim Pengembang Pedoman Bahasa Indonesia, Pedoman Umum Ejaan Bahasa Indonesia, 2016, [Online] Available: http://badanbahasa.kemdikbud.go.id/lamanbahasa/sites/default/files/P UEBI.pdf [2019, Maret 19/12:20]

[15] Wibowo, Aan Tri, "Pembuatan Aplikasi E-Commerce Pusat OlehOleh Khas Pacitan Pada Toko sari rasa Pacitan Indonesian”, Journal on Networking and Security (IJNS). Vol.2 No.4, 2013 [Online] Tersedia di: http://ijns.org/journal/index.php/ijns/article/view/247 [diunduh: 01 Maret 2019], hal 64 